appeared wholly nebulous, with a bright central condensation; the tail broad, but faint. I could only trace it some $2^{\circ}$ or $3^{\circ}$. The brightness of the nucleus must have been considerable, as when close to the horizon I could see it through a pretty thick cloud. Subsequently the nucleus has seemed to me decidedly more disk-like, I suppose from being better seen. I may add that the sunset-glows and the unusually cloudy weather we are having have interfered greatly with satisfactory observation.

Nelson, N.Z., February I

A. S. AtKinson

\section{The Access to Mountains and Moorlands Bill}

I AM glad to observe that you have called the attention of scientific men to the importance of Mr. Bryce's Bill. Perhaps nothing can better show the need of such a measure than certain facts in regard to the Clova district in Forfarshire, which is classic ground to the botanist; indeed, I think I may venture to say that it is the richest ground in the British Islands. From time immemorial a right of way existed through Glen Dale, and, I can remember the time when botanists could ascend any of the hills in that district without being subjected to the tender, though somewhat embarrasing attention of gamekeepers. I have good reason to believe that the case is somewhat altered in recent years, and that, after a man has gone hundreds of miles in order to see Oxytropis campestris growing in its only British station, he may find himself turned back just within sight of the goal. The thing can still be done by taking advantage of a curious fact in natural history, viz. that two gamekeepers cannot remain long in loving converse with three men : by keeping this fact in mind, one out of three may still study the bstany of Clova. After having gone pretty well over Scotland I am glad to say that there are many places in which there is no need for Mr. Bryce's Bill. In most cases in which it is needed it is where "new men" usurp a power which the old lords of the soil never dreamt they possessed.

Edinburgh, March 24

\section{A Sixth Sense}

In the valuable address given by Sir William Thomson at the Midland Institute, Birmingham, on October 3, and reported so fully in the columns of NATURE, it is implied that Irr. Thomas Reid of Glasgow brought out the distinction of a sixth or muscular sense. I cannot find any satisfactory evidence of this, although Reid came very near it indeed when he stated in his "Inquiry into the Human Mind," chap. v. section I :- "By touch we perceive not one quality only, but many, and those of very different kinds;" and again :-- "There is, no doubt, a sensation by which we perceive a body to be hard or soft;" and again, further on he even speaks of its being strange that this sense should " be so much unknown as never to have been made an object of thought or reflection nor to have been honoured with a name in any language."

And on the other hand, while I cannot detect any attempt whatever to refer this sensation to the muscles as its peripheral origin, while speaking of our conception of the hardness of bodies, Dr. Reid says (p. 121, ed. of 1846) :-" We have no way of coming at this conception and belief, but by means of a certain sensation of touch;" and again, "I see nothing left but to conclude that, by an original principle of our constitution, a certain sensation of touch both suggests to the mind the concep. tion of hardness and creates a belief of it." Reid, in short, like his eminent predecessor Hutcheson in the same chair, was di:sati-fied with the ordinary division of the senses, and really felt disposed to split up the varied phenomena bundled up under the term "touch" into two or more divisions; but it was reserved for Dr. Thomas Brown, a good physiologist according to the light of the times, and Processor of Moral P'hilosophy is Edinburgh (I8IO-20), explicitly to complete the distinction hinted at by Keid, and to refer our conception of resistance or tension (as we find in estimating weights by the hand) to a distinct sixth or muscular sense. Thus in his twenty-second lecture he says :- "The feeling of resistance is, I conceive, to be ascribed, not to an organ of touch, but to our muscular frame, to which I have already more than once directed your attention, as forming a distinct organ of sense." In the lecture which follows that, Brown admits the frequent mingling of mere tactual sensation with that of muscular effort :"But it is not of this mere tactual feeling we think when we term bodies hard or soft-it is of the greater or less resistance which they afford to our muscular contraction."
It is remarkable that the teaching of this eminent psychologist, the preceptor of James Mill, should so early have been forgotten in Scotland.

Laurel Bank, Shawlands, Glasgow, March i8

Mr. FAULDS, in the preceding letter, is no doubt quite correct in remarking that the distinction pointed out and insisted on (not merely hinted at) by Thomas Reid, a little more than a hundred years ago, in the Moral Philosophy Chair of the University of Glasgow, was more clearly and fully defined by his eminent successor in Edinburgh, Thomas Brown. But I cannot agree with his last sentence, implying that Thomas Brown is forgotten in Scotland. In fact, my mind was so full of Reid and Brown, from my recollections of the teachings of the Professors of Moral Philosophy and Logic in this University, that, in giving my address at Birmingham, I said Thomas Brown, meaning Thomas Reid, but feeling the names of Reid and Brown both thoroaghly mixed up with all I had ever learned of this subject.

The University, Glasgow, March 20 William THOMSON

\section{Earthworms}

THE theory of the formation of vegetable mould through the action of earthworms, by Darwin, received little attention when published from people who had been accustomed to examine the soils of various countries. That the vegetable soil had been formed as he states seemed to have been accepted by his followers without hesitation. In your columns, however, of late, letters have appeared from Messrs. K. M. Christy and T. E. Wilcox, showing that earthworms do not exist in the prairies in the north-w est of Canada or in the United States, in those of Kansas, the Indian Territory, or in Idaho and Washington Territory. This is simply what may be expected. Notwithstanding the keenness of observation of Darwin and his width of observation, there seem vast regions where earthworms have had little to do with the formation of the vegetable soil. In many parts of Australia, and also in the moister climate of New Zealand, the soil affords few indications that earthworms ever passed it through their bodies. In a section of soil I brought from the Mataura plain, South Island of New Zealand, nothing could be seen to indicate that worms had ever swallowed it. That vegetable soil forms a fit babitation for earthworms is undoubted, Darwin admits "that a layer, though a thin one, of fine earth, which probably long retains some moisture, is in all cases necessary for their existence." Before this thin layer existed, how could they-the worms-form vegetable soil? This thin layer must have been formed in some other way; Darwin does not say how. It is not necessary to call in the aid of earthworms to do so. The very name which has been universally applied to the thin upper covering, the exterior film enveloping the surface of the deposits underneath, viz. vegetable soil, speaks to its origin in the decay of vegetation. Take for instance the boulder-clays of this part of the Lothians in Scotland, with their tough, stony texture, their pebbles as finely striated as when the ice squeezed them into the pasty mass of crushed shales out of which they appear to have been partly formed. While these surfaces could have afforded none of the conditions required by Darwin, or indeed supply any other save inorganic food, the slow growth on their surfaces of the more simple forms of vegetable life, and their decay, would in the lapse of ages supply the thin film which Darwin requires. It surely, then, is attempting too much to ascribe to the earthworm the formation of the vegetable sail. The earthworm is not the ouly occupant of the material which the growth and decay of vegetation supplies as a surface covering. The earthworm is not the only drainer. The roots of many plants not only descend deeply into the subsoils, but also fetch up from depths where worms could not reach supplies of material to mix with the superticial coveriny; and so do the various insects which have their habitat in the soil, burrowing as they go, and casting, like the mole, the stuff behind them or upwards as they descend.

So far as I have examined soils, I am inclined to think that the earthworm is far more plentiful when animal matter in a decaying state is applied to soils near the dwellings of man, or when his deposits are laid over those of the laryer animals. As against the views of Hutton and Playfair, and as stated by Darwin, that the vegeiable soil or mould is always diminishing, I have to say it seems entirely the reverse; it seems to have had a be- 